\title{
Red cell enzyme tests of vitamin status: do marginal deficiencies have any physiological significance?
}

\section{By D. I. Thurnham, Department of Human Nutrition, London School of Hygiene $E^{\circ}$ Tropical Medicine, Keppel Street, London $W C_{1} E_{7} H T$}

My task at this symposium was to discuss the three B-vitamins, thiamin, riboflavin and pyridoxine and the respective red cell enzymes transketolase (TK; sedoheptulose-7-phosphate: D-glyceraldehyde-3-phosphate glycolaldehyde transferase; $E C$ 2.2.1.I), glutathione reductase (GR; $\mathrm{NADPH}_{2}$ : glutathione oxidoreductase; $E C$ I.6.4.2) and either aspartate aminotransferase (AST; L-aspartate: 2oxoglutarate aminotransferase; $E C$ 2.6.I.I) or alanine aminotransferase (ALT; Lalanine: 2-oxoglutarate aminotransferase; $E C$ 2.6.1.2) used in the assessment of their nutritional adequacy. It was not my intention to describe the classical diseases which are caused by severe deficiencies of these vitamins but rather to try to evaluate the risks which might be linked with what is known as marginal or biochemical deficiency and attempt to assess the importance of measuring vitamin status in man and animals by discussing the work which links marginal deficiencies of these vitamins with changes in physiological function or increased risk of morbidity or mortality. Before examining the risk aspect of marginal vitamin deficiencies, however, it is necessary first of all to mention those factors which interfere with red cell enzyme activity and affect the assay.

The enzyme assays

The enzymes TK, GR, AST and ALT require their respective co-enzymes, thiamin pyrophosphate (TPP), flavin adenine dinucleotide (FAD) and pyridoxal phosphate (PP) for activity and to assess the extent of in vivo unsaturation the enzymes are measured in vitro with and without the appropriate co-enzyme. The ratio of enzyme activity with added co-enzyme to that without is known as the activation coefficient (AC) and the higher the value, the greater the deficiency. AC greater than $I \cdot 25$ and $I \cdot 30$ for thiamin and riboflavin status and of $1 \cdot 25$ and $I \cdot 50$ for the ALT and AST assays respectively are regarded as being deficient (Sauberlich et al. 1974).

Red cell enzymes appear to be among the first tissues to be affected by a depletion of vitamins (Brin et al. 1960; Raica \& Sauberlich, 1964; Glatzle et al. 1973) and in general the rise in $A C$ is accompanied by a fall in basic enzyme activity, that is the activity measured in the absence of added co-enzyme. However, these changes do not necessarily run in parallel and the behaviour of these two indices is influenced by factors which affect the activity of both holoenzyme (i.e. basic activity) and apo-enzyme.

Red cell enzyme activity declines as the cells age (Sass et al. 1964). This is $0029-605^{1 / 81} / 4023-5002$ Sor.00 C 1981 The Nutrition Society 
certainly so in the case of TK (Wells \& Marks, 1972), GR (Ganzoni et al. 1976; Powers \& Thurnham, 1976) and AST (Sass et al. 1964) and the basic enzyme activity of a red cell population is influenced by the mean cell age (Powers \& Thurnham, 1976). Thus TK activity is increased in patients with iron deficiency who respond to treatment by a reticulocylosis (Wells \& Marks, 1972; Kjøsen \& Sein, r977) and GR activity is elevated in subjects with glucose-6-phosphate dehydrogenase deficiency (Flatz, 1971). A high basic enzyme activity will tend to depress the AC (Thurnham et al. 1979).

\section{Transketolase}

The wide range of TK activities has been commented on by many workers (Sauberlich, I967; Bamji, 1970; Wood et al. 1977). Differences between means of different patient groups and controls however are not usually significant. The variability in enzyme activity may be partly due to instability. The TK apoenzyme is unstable in vitro (Chong \& Ho, 1970; Bayoumi \& Rosalki, 1976) and appears also to be unstable in vivo, for Bamji (1970) has reported that after 2-3 weeks of deficiency, in experimental studies in man, TPP fails to stimulate TK activity in vitro to its original activity. Low $\mathrm{TK}$ activities may also be due to marginally low thiamin intakes in the population. Brin ( 1962 ) noted that red cell TK activity in rats was $24-30 \%$ below controls within a week of placing animals on a deficient diet. At this stage the $\mathrm{AC}$ was only $\mathrm{I} \cdot \mathrm{I}$. In other words basic $\mathrm{TK}$ activity may be a better measure of thiamin status than the $\mathrm{AC}$, as has recently been suggested by Wood et al. (1977) on the basis of a better association between this index and their clinical information.

\section{Glutathione reductase and other enzymes}

In contrast to TK however red cell GR activity is far more stable in vitro (Thurnham et al. 1970; Nichoalds et al. 1974) although this was not confirmed by Bayoumi \& Rosalki (1976). In our experience too, low GR activities are usually accompanied by an elevated $\mathrm{AC}$ and most workers in this field report only the AC (Sauberlich et al. 1972; Tillotson \& Baker, 1972; Buzina et al. 1973; Hill et al. 1977; Lopez et al. 1978; Department of Health \& Social Security, 1979). Of the two transaminases used to assess pyridoxine status, ALT is regarded as the more sensitive as the change in $A C$ on vitamin depletion is greater (Cinnamon \& Beaton, 1970; Woodring \& Storvic, 1970). Basic ALT activity in the red cell however is only one-twentieth of that of AST (Raica \& Sauberlich, I964), is far less stable on storage in vitro (Rose et al. 1973) appears to have lower activity in women (Rose et al. 1972) and has been found to decline with age (Jacobs et al. r968). The activity of AST on the other hand is increased by oestrogens and corticosteroids (Aly et al. 1971; Rose et al. 1973) and is more prone to day to day fluctuations but it can be more easily measured on 'finger-tip' blood samples (D. I. Thurnham, unpublished observations). In our experience, working on blood from elderly people, from one-third to one-half of AST activity in the red cell is present as the apo-enzyme. This relatively large pool of AST apo-enzyme probably combines 
with or disassociates from circulating PP relatively easily, hence accounting for the variable basic activity.

The fact that oestrogens increased basic AST activity (Rose et al. I973) has been mentioned. This is contrary to what would be expected from the many reports, based on the tryptophan load test, that oestrogen-containing oral contraceptives impair pyridoxine status (Rose, 1966; Rose et al. 1972; Winston, 1973). Measurements of red cell ALT or AST activities in oral contraceptive users however, do not indicate a pyridoxine deficiency and although Rose et al. (1973) reported that the ALT AC of oral contraceptive users were significantly elevated by comparison with controls, the respective $A C$ values were (mean $\pm S D$ ) I $25 \pm 0 \cdot 2$ I and I.I8 $\pm 0 \cdot 14$. A large number of subjects in both groups would have had values within the normal or deficient range, whichever way you look at it. Furthermore, the mean basic ALT activity of the contraceptive users group was higher than that of the control group although the difference was not statistically significant. It is true however that the administration of large quantities of pyridoxine corrects the abnormalities in tryptophan metabolism associated with the taking of oral contraceptives but the effect of the drugs may not be to cause a general pyridoxine depletion but rather to interfere with certain pyridoxine dependent enzyme systems.

With the exception of pyridoxine, there are very few reports of drugs which directly influence the enzymes under discussion. However, two drugs have been reported recently to impair thiamin metabolism as indicated by the response of the TK assay. 5-Fluorouracil, a cytotoxic drug used in the treatment of cancer, was reported to impair thiamin status in rats (Basu et al. 1979) and the well-being of patients was improved following thiamin supplementation (Dickerson, 1981). Frusomide, a diuretic, was recently shown to impair the thiamin status of both normal and thiamin-deficient rats (Yui et al. 1980). The latter is particularly noteworthy since the drug is used in the treatment of congestive heart failure which is associated with cardiac beriberi but which might not initially be diagnosed as the reports of Golden \& Connon (1972) and Elkin et al. (1972) indicate. The mechanism of action in both cases is not known.

\section{Physiological changes associated with marginal deficiencies}

Marginal vitamin deficiencies may have different effects on the body's metabolism which will depend on the stage of life and the demands facing its normal development. Growth restrictions, degenerative changes in tissues, foetal abnormalities, interference with milk production or composition, increased susceptibility to infection, altered response to dietary constituents, diminished work ability etc. are some of the possible effects of chronic marginal restrictions in the diet. Our knowledge of the specific effects of nutrient deficiencies is derived mainly from depletion studies, but such experiments are essentially short term in man to avoid irreversible side effects and are restricted usually to fully grown, healthy adults. They are highly artificial by comparison to those situations where the deficiencies occur naturally. Depletion studies do give some indications 
however, concerning early changes in physiological functions and these will be mentioned where they are relevant. The chronic conditions which have been speculatively linked with marginal deficiencies and their biochemical explanations will also be discussed. It is generally accepted that biochemical change precedes the appearance of clinical signs and where possible attempts will be made to quantify the relationship between the appearance of the signs and the biochemical status.

\section{Thiamin}

Brin $(1962 ; 1964)$ has described the sequence of physiological and clinical changes and corresponding $\mathrm{TK}$ values during an acute experiment in men deprived of thiamin. Between the third and fourth weeks, TK indices were within the deficient range and accompanied such changes as loss of appetite and weight, irritability, insomnia and malaise. By the sixth week, the biochemistry had worsened and there were many of the signs indicative of the symptomatology of early beriberi, e.g., polyneuritis, bradycardia, peripheral oedema, ophthalmoplegia etc. This experiment indicated the rapidity with which the debilitating signs affecting heart and nervous tissues can appear but also the non-specific nature of the signs accompanying marginal thiamin nutrition. Classical beriberi has virtually disappeared from both developed and developing countries and, with the exception of the occasional person on an inappropriate slimming diet, (Sotaniemi \& Kaarela, 1977), thiamin deficiency in the West is almost always associated with alcoholism in the form of the Wernicke-Korsakoff syndrome. It has been reported that the presence of thiamin-fortification schemes in a country significantly reduce hospital admissions for Korsakoff's Psychosis (Wood \& Breen, 1980). That is, even in a well-nourished community, an artificially elevated thiamin intake may help to protect chronic alcoholics against the dangers of thiamin deficiency.

The value of added thiamin to the diet of the majority of the population is not so easily assessed. The clinical signs associated with marginal thiamin deficiency are too non-specific for any useful investigation of a relationship with the TK indices. However, there may be some association between these signs and thiamin status for a literature search by Zbinden ( 1962$)$ found the physicians used thiamin for 230 different diseases. His conclusions were, however, that thiamin was indicated only for neuropathies, chronic alcoholism and pregnancy and that therapeutic success was best when there was evidence of nutritional imbalance, vomiting and intestinal malabsorption. Recent surveys of pregnant women have found raised TK-AC in a number of women (Chong \& Ho, I970; Heller et al. 1974), but it is questionable what beneficial effects therapy would have had. Heller et al. (r 974) could find no correlation between thiamin status and the outcome of pregnancy but it is not known whether the wellbeing of the mother might have been improved by therapy. Lastly, it has been suggested that many of the idiopathic dementias in the elderly (more than half are of unknown aetiology) may be due to a failure of mechanisms of vitamin transport across the choroid plexus to the brain (Spector et al. I979). TK activity would probably not be of much use in attempts to test this hypothesis as it would not indicate thiamin availability in the brain. 


\section{Riboflavin}

The response of the EGR-AC to a deprivation of riboflavin from the diet of young men was studied by Tillotson \& Baker (1972). The AC rose above $\mathrm{I} \cdot 3 \mathrm{O}$ in most of the subjects from the end of the second week. In contrast to the effect of a thiamin deficiency, however, no clinical signs appeared during the 8 week study although behavioural tests revealed significant changes from the sixth week and a decline in hand-grip strength (Sterner \& Price, 1973).

Classically, angular stomatitis, cheilosis and glossitis are the signs associated with riboflavin deficiency. These signs are not specific, however, for ariboflavinosis nor is the appearance of signs correlated with the degree of biochemical deficiency (Thurnham et al. 1971; Buzina et al. 1973). Furthermore, apart from the nuisance value of the mouth signs, they are not in themselves of economic importance.

Some of the metabolic reactions which riboflavin supports through its role as a co-enzyme may have physiological significance if restricted through a lack of riboflavin. Reduced glutathione (GSH), the product of GR activity, is required by tissues for a variety of purposes; maintaining suphydryl-containing enzymes in an active state, maintaining haemoglobin in its native form, amino acid transport (Beutler, r975) metabolism of thyroid hormones (Visser, I980) etc. Oxidation of GSH appears to occur primarily through the mediation of the enzyme glutathione peroxidase ( $E C$ I.II.I.9) which protects the cell by removing lipid peroxides (Chow et al. 1973). Hassan \& Thurnham (1977) have shown that various aspects of this metabolism in the red cells of severely riboflavin-deficient rats are disturbed. The concentration of red cell GSH was reduced while that of methaemoglobin and lipid peroxides was increased. In marginally riboflavin-deficient humans, however, it was not possible to confirm any of these alterations except for a small increase in methaemoglobin (H. J. Powers and D. I. Thurnham, unpublished results) although it was possible to demonstrate an increased proportion of young red cells in the circulation by comparison with blood from control subjects (Powers \& Thurnham, I980). A reduced efficiency of GR and associated enzymes might impair the stability of the red cell, shorten its life and increase erythropoiesis. Recent studies in riboflavin-deficient rats support this possibility since using an $\mathrm{Fe}^{59}$-labelled cohort of red cells to measure the half life showed that there was evidence of earlier disappearance of red cells since radio-activity disappeared more rapidly in the deficient animals although half life was not reduced. The effect may be partly due to inanition, however, since there was a similar but smaller disappearance in weight-matched controls (C. Port, personal communication).

Anaemia has been reported in riboflavin-deficient man, baboons, rats and other species (Foy \& Kondi, r953; 1 968) and it occurs extensively throughout the world where riboflavin deficiency is found. Red cell instability may contribute to the aetiology of such anaemia since any increase in red cell turnover will increase requirements for all haemopoietic factors, some of which (e.g. folate, iron) may be 
limiting in the diets of the developing and sometimes the developed world. Additionally, it has been reported that riboflavin is necessary for the conversion of ferric and ferrous iron in its mobilization from ferritin and that riboflavin deficiency impairs iron mobilization (Sirivech et al. 1976).

Riboflavin deficiency may also play a role in cancer development. Experimental studies suggest that in most cases a riboflavin deficiency will inhibit tumor growth but with some carcinogens e.g. azo dyes, the potency of the drugs is increased (Rivlin, 1973). Riboflavin has also attracted attention from physicians interested in the aetiology of oesophageal cancer since riboflavin is essential for maintaining the integrity of squamous epithelium (Wynder \& Klein, 1965). Early studies on patients with the Plummer-Vinson disease which commonly develops into oesophageal cancer (Wynder et al. 1957) showed that it presented in its earlier stages evidence of iron and B-vitamin deficiencies, particularly riboflavin (Wynder \& Fryer, 1958). More recently studies in Northern Iran, in an area with a particularly high incidence of oesophageal cancer, found $80 \%$ of the population to have chronic oesophagitis (Crespi et al. 1979) while independent studies in both high and low cancer-risk areas in the same region found extensive biochemical and clinical evidence or riboflavin deficiency (Kmet et al. 198I).

It is not suggested that riboflavin deficiency itself is carcinogenic but rather that a chronic deficiency may make epithelial tissues more susceptible to some environmental factor which is itself damaging. For example, riboflavin deficiency in rats was found to make the animals more susceptible to artificially-induced gastric ulcers (Kim \& Lambooy, ${ }_{1967}$ ). The role of glutathione peroxidase in removing toxic lipid hydroperoxides may have great importance in maintaining stability of epithelial tissue. Free-radical oxygen is probably the active species which attacks unsaturated lipid forming the hydroperoxides. Oxygen toxicity is controlled notably by dismutase ( $E C$ I.I5.I.I) and glutathione peroxidase (Fridovich \& Hassan, I979) and can adjust to external changes. The exposure of rats to sublethal quantities of ozone increased glutathione peroxidase, GR and glucose-6-phosphate dehydrogenase activities and GSH concentrations in their lungs (Chow, 1976). It is conceivable that riboflavin deficiency may restrict GR activity from increasing its production of GSH and thus impair the organism's response to external stress.

Riboflavin status has been examined in many sections of the community. High $A C$ are not common in new born or young infants (Thurnham et al. 197I; Cooperman et al. 1973) but in other sections of the community some deficient subjects are usually found and sometimes there is a high prevalence as in black high-school girls $(38 \%)$ (Sauberlich et al. 1972$)$ and the elderly in the UK (30\%) (Thurnham \& Stephen, 1975; Department of Health \& Social Security, 1979). Deficiencies have been reported in children with diabetes (Cole et al. 1976) or heart disease (Steier et al. 1976) and in adults in association with presenile cataracts (Prchal et al. 1978) in users of oral contraceptives (Sanpitak \& Chayutimonkul, 1974) in surgical patients (Hill et al. 1977) etc. The question rarely asked, however, is whether the deficiencies are of any importance.

Thurnham et al. (1972) suggested that marginal riboflavin deficiency in Thai 
village children might be contributing to their stunted growth since hydroxyproline excretion was stimulated by riboflavin supplements. The increase in hydroxyproline excretion, however, was not correlated with the degree of riboflavin deficiency. Cataract formation is common in laboratory animals on flavin-deficient diets (Day et al. 1931) but the role of riboflavin deficiency in cataract formation in man is still equivocal (Prchal et al. 1978). Smithells et al. (1980) recently reported that a periconceptional vitamin supplement ('Pregnavit Forte F' Bencard) which includes riboflavin, given to women who had previously given birth to one or more child with a neural tube defect (NTD) was associated with a very large reduction in the expected number of subsequent NTD births. Congenital malformations in the offspring of riboflavin-deficient rats have been reported (Gilman et al. 1952) but it is not possible to say yet whether the results reported by Smithells and coworkers are due to any one particular vitamin.

\section{Pyridoxine}

Finally, reports concerning pyridoxine deficiency have in general concerned drugs, e.g. oral contraceptives, alcohol, isoniazid etc.; primary dietary deficiency appears to be rare and dietary intake is usually adequate (Department of Health \& Social Security, 1970). Pyridoxine deprivation has been reported to cause in the early stages, fatigue and headaches (Cinnamon \& Beaton, 1970) and later, microcytic anaemia (Bourne et al. 1965), infantile convulsions (Scriver, 1960) while Krishnaswamy (1971) reported that patients with oral lesions and sensory neuritis responded to treatment with pyridoxine.

The effects of oestrogen on pyridoxine metabolism, as brought about by oral contraceptives or pregnancy, have been implicated as a possible cause of the occasionally associated mental depression and impaired glucose tolerance. There is considerable evidence that a failure of normal brain 5 -hydroxytryptamine (5HT) synthesis from L-tryptophan may be important in the aetiology of depression (Curzon, 1969). The effects of oestrogen may be to deplete both tryptophan or the PP necessary for the enzymic synthesis of 5 -HT or both (Rose \& Adams, 1972). Another consequence of the abnormal tryptophan metabolism is an increase in urinary xanthurenic acid, a substance which will bind to insulin, impairing its ability to lower blood glucose (Murakami \& Kotake, 1972). Liver disease appears to impair pyridoxine metabolism both by suppressing the formation and by increasing the breakdown of PP (Labadarios et al. 1977). Riboflavin deficiency has also been reported to impair the synthesis of PP (Lakshmi \& Bamji, 1974) but it was not possible to demonstrate any increase in numbers of subjects with pyridoxine deficiency amongst elderly subjects with riboflavin deficiency in the UK (D. I. Thurnham, unpublished results).

In conclusion, use of the TK indices has generally been done to evaluate the risk of beriberi or Wernicke's syndrome in the community. The aminotransferase enzymes have had limited use in the community by contrast with the other two enzyme tests since most reports dealing with pyridoxine status are concerned with side effects of drug metabolism and have often used alternative methods. GR, 
however, has been used extensively in surveys and the associations of marginal riboflavin deficiency with anaemia, certain cancers, cataracts and congenital malformations make it well worth further study.

\section{REFERENCES}

Aly, H. E., Donald, E. A. \& Simpson, M. H. W. (1971). Am. F. clin. Nutr. 24, 297.

Bamji, M. S. (1970). Am. F. clin. Nutr. 23, 52.

Basu, T. K., Aksoy, M. \& Dickerson, J. W. (1979). Chemotherapy 25, 70.

Bayoumi, R. A. \& Rosalki, S. B. (1976). Clin. Chem. 22, 327.

Beutler, E. (1975). Life Sci. 16, 1499 .

Bourne, M. S., Elves, M. W. \& Israels, M. C. G. (1965). Br. F. Haematol. I1, I.

Brin, M. (1962). Ann. N.Y. Acad Sci. 98, 528 .

Brin, M. (1964). F. Am. Med. Assoc. 187, 762 .

Brin, M., Tai, M., Ostashever, A. S. \& Kalinsky, H. (1960). F. Nutr. 71, 273.

Buzina, R., Brodarec, A., Juśic, M., Milanovic, N. \& Kolombo, V. (1973). Int. Z. VitamForsch. 43, 4 or.

Chong, Y. H. \& Ho, G. S. (1970). Am. F. clin. Nutr. 23, 26 r.

Chow, C. K. (1976). Nature, Lond. 260, 27 r.

Chow, C. K., Reddy, K. \& Tappel, Al. L. (1973). 7. Nutr. 103, 618.

Cinnamon, A. D. \& Beaton, J. R. (1970). Am. F. clin. Nutr. 23, 696.

Cole, M. S., Lopez, R. \& Cooperman, J. M. (1976). Acta Diabetol. Lat. 13, 25.

Cooperman, J. M., Cole, H. S., Gordon, M. \& Lopez, R. (1973). Proc. Soc. exp. Biol. Med. 143, 326.

Crespi, M., Munoz, N., Grassi, A., Aramesh, B., Amiri, G. \& Mojtabai, A. (1979). Lancet ii, 2 r 7.

Curzon, G. (1969). Br. F. Psychiat. I15, 1367.

Day, P. L., Langston, W. C. \& O'Brien, C. S. (1931). Am. J. Ophthal. 14, 1005.

Department of Health \& Social Security (1970). Rep. Publ. Hlth Med. Subj. No. I20. Recommended Intakes of Nutrients for the United Kingdom. London: HM Stationery Office.

Department of Health \& Social Security (1979). Rep. Hlth Soc. Subj. No. 16. Nutrition \& Health in Old Age. London: HM Stationery Office.

Dickerson, J. W. T. (1981). Proc. Nutr. Soc. 40, 31 .

Elkin, F., Pierce, T. H. \& Gatenby, P. B. B. (1972). F. Ir. med. Ass. 65, 195.

Flatz, G. (1971). Humangenetik Ir, 22 I.

Foy, H. \& Kondi, A. (1953). f. Path. Bact. 65, 559.

Foy, H. \& Kondi, A. (1968). Int. Symp. Vit. Reld Anaemias, vol. 26. London: Academic Press.

Fridovich, I. \& Hassan, H. M. (1979). Trends biochem Sci. 4, II 3 .

Ganzoni, A. M., Barras, J. P. \& Mart, H. R. (1976). Vox Sang. 30, 161.

Gilman, J. P. W., Perry, F. A. \& Hill, D. C. (1952). Can. F. med. Sci. 30, 383.

Glatzle, D., Weiser, M., Weber, F. \& Wiss, O. (1973). Int. Z. VitamForsch. 43, 187.

Golden, M. H. N. \& Connon, J. J. (1972). F. Ir. med. Ass. 65, 193.

Hassan, F. M. \& Thurnham, D. I. (1977). Int. Z. VitamForsch. 47, 349.

Heller, S., Salkeld, R. M. \& Körner, W. F. (1974). Am. F. clin. Nutr. 27, 221.

Hill, G. L., Blackett, R. L., Pickford, I., Burkinshaw, L., Young, G. A., Warren, J. V., Schorah, C. J. \& Morgan, D. B. (1977). Lancet i, 689.

Jacobs, A., Caville, I. A. J. \& Hughes, J. N. P. (I968). Am. J. clin. Nutr. 21, 502.

Kim, Y. S. \& Lambooy, J. P. (ig67). F. Nutr. 98, 467 .

Kjøsen, B. \& Sein, S. H. (1977). Am. F. clin. Nutr. 30, I591.

Kmet, J., McLaren, D. S. \& Siassi, F. (1981). In Advances in Modern Human Nutrition. [M. A. Mehlman, editor]. Illinois: Pathotox.

Krishnaswamy, K., (1971). Int. Z. VitamForsch. 41, 240.

Labadarios, D., Rossouw, J. E., McConnell, J. B., Davis, M. \& Williams, R. (1977). Gut 18. 23.

Lakshmi, A. V. \& Bamji, M. S. (1974). Br. Y. Nutr. 32, 249.

Lopez, R., Gromisch, D. S., Cole, H. S. \& Cooperman, J. M. (2978). Proc. Soc. exp. Biol. Med. I57, $4 \mathrm{I}$. 
Murakami, E. \& Kotake, Y. (1972). f. Biochem. 72, 251.

Nichoalds, G. E., Lawrence, J. D. \& Sauberlich, H. E. (1974). Clin. Chem. 20, 624.

Powers, H. J. \& Thurnham, D. I. (1976). Nutr. Metab. 21 (Suppl. I), I 57.

Powers, H. J. \& Thurnham, D. I. (1980). Proc. Nutr. Soc. 39, I7A.

Prchal, J. T., Conrad, M. E. \& Skalka, H. W. (1978). Lancet i, 12.

Raica, N. \& Sauberlich, H. E. (1964). Am. F. clin. Nutr. 15, 67.

Rivlin, R. S. (1973). Cancer Res. 33, 1977.

Rose, D. P. (1966). Clin. Sci. 31, 265.

Rose, D. P. \& Adams, P. W. (1972). F. clin. Path. 25, 252.

Rose, D. P., Strong, R. Adams, P. W. \& Harding, P. E. (1972). Clin. Sci. 42, 465.

Rose, D. P., Strong, R., Folkard, J. \& Adams, P. W. (1973). Am. F. clin. Nutr. 26, 48.

Sanpitak, N. \& Chayutimonkul, L. (1974). Lancet i, 836 .

Sass, M. D., Vorsanger, E. \& Spear, P. W. (1964). Clin chim. Acta 10, 21.

Sauberlich, H. E. (1967). Am. F. clin. Nutr. 20, 528 .

Sauberlich, H. E., Dowdy, R. P. \& Skala, J. J. (1974). In Laboratory Tests for the Assessment of Nutritional Status. Cleveland: CRC Press.

Sauberlich, H. E., Judd, J. H. Jr, Nichoalds, G. E., Broquist, H. P. \& Darby, W. J. (1972). Am. F. clin. Nutr. 25,756 .

Scriver, C. R. (1960). Pediatrics, Springfield 26, 62.

Sirivech, S., Osaki, S. \& Frieden, E. (1976). Biochem. F. 43, 311.

Smithells, R. W., Sheppard, S., Scorah, C. J., Seller, M. J., Nevin, N. C., Harris, R., Read, A. P. \& Fielding, D. W. (r980). Lancet i, 339 .

Sotaniemi, K. A. \& Kaarela, K. (1977). Br. Med. F. 2, I635.

Spector, R., Cancilla, P. \& Damasio, A. (1979). Med. Hypoth. 5, 763.

Steier, M., Lopez, R. \& Cooperman, J. M. (I976). Am. Heart. $\mathscr{F} .92,139$.

Sterner, R. T. \& Price, W. R. (1973). Am. f. clin. Nutr. 26, 150.

Thurnham, D. I., Hassan, F. M. \& Powers, H. J. (1979). In The Importance of Vitamins to Human Health pp. 27-40. Lancaster: MTP Press.

Thurnham, D. I., Migasena, P. \& Pavapootanon, N. (1970). Mikrochim. Acta 5, 988.

Thurnham, D. I., Migasena, P. \& Supawan, V. (1972). Br. F. Nutr. 28, 99.

Thurnham, D. I., Migasena, P., Vudhivai, N. \& Supawan, V. (1971). S.E. Asian f. trop. Med. pub. Hith 2, $55^{2}$.

Thurnham, D. I. \& Stephen, J. M. L. (1975). Xth Int. Congr. Nutr., Kyoto. Abstr. 6340 p. 302.

Tillotson, J. A. \& Baker, E. M. (1972). Am. J. clin. Nutr. 25, 425.

Visser, T. J. (1980). Trends biochem. Sci. 5, 222.

Wells, D. G. \& Marks, V. (1972). Acta Haematol. 47, 217.

Winston, F. (1973). Am. F. Psychiat. 130, 1217.

Wood, B. \& Breen, K. J. (1980). Med. J. Aust. 1, 461.

Wood, B., Breen, K. J. \& Penington, D. G. (1977). Aust. N.Z. F. Med. 7, 475.

Woodring, M. \& Storvic, C. (1970). Am. F. clin. Nutr. 23, I385.

Wynder, E. L. \& Fryer, J. H. (1958). Ann. intern. Med. 49, 106.

Wynder, E. L., Hultberg, S. Jacobsson, F. \& Bross, I. J. (1957). Cancer 10, 470.

Wynder, E. L. \& Klein, U. E. (1965). Cancer 18, 167.

Yui, Y., Złokawa, Y. \& Kawai, C. (1980). Cardiovascular Res. (In the Press).

Zbinden, G. (1962). Ann. N.Z. Acad. Sci. 98, 550. 